Dokuz Eylül Üniversitesi-Mühendislik Fakültesi

Fen ve Mühendislik Dergisi

Cilt 19 Sayı 55 Ocak 2017
Dokuz Eylul University-Faculty of Engineering Journal of Science and Engineering Volume 19 Issue 55 January 2017

DOI: $10.21205 /$ deufmd. 2017195519

\title{
Değişik Deşarj Oranlarında Zarf Batarya Hücresinin Isıl İncelemesi
}

\section{Gamze GEDiZ İLiş ${ }^{* 1}$}

${ }^{1}$ Okan Üniversitesi,Mühendislik Fakültesi, Makina Mühendisliği Bölümü, 34959, İstanbul

(Alınış / Received: 19.07.2016, Kabul / Accepted: 14.11.2016, Online Yayınlanma / Published Online: 09.01.2017)

Anahtar Kelimeler Özet: Batarya hücresi içerisindeki ısı üretimi bataryaların Batarya

Modelleme, Zarf

Batarya Hücresi,

Isı Üretimi,

Deneysel Çalıșma,

Sayısal Analiz ömürlerini açısından en önemli faktörlerden biri olmaktadır.Bataryaların günlük hayatta kullanımının artması nedeni ile, bataryaların ısıl analiz metotları araştırmacılar tarafından önem kazanmaktadır. Bu çalışmada, zarf tipi batarya hücresi içerisindeki ısı üretimi incelenmiştir. Sayısal sonuçları doğrulamak için $3.7 \mathrm{~V}, 2.1 \mathrm{Ah}$ batarya hücresine $1 \mathrm{C}$ ve $2.5 \mathrm{C}$ deşarj oranlarında deney yapılmıştır. Elektriksel eşit devre ısıl modeli batarya hücresindeki ısı üretimini modellemek için ele alınmıştır. Sayısal sonuçların deneysel veriler ile karşılaştırılması sayısal ve deneysel sonuçlarda iyi bir uyum olduğunu göstermiştir. Model ile deneysel sonuçlar \%4 hata payı içerisinde doğrulanmıştır. Buna göre hazırlanan model diğer deşarj oranlarında da kullanılabilecektir.

\section{Thermal Investigation of Pouch Battery Cell with Different Discharge Rates}

\begin{abstract}
Keywords
Battery

Modelling, Pouch

Battery Cell, Heat

Generation,

Experimental

Study, Numerical

Analysis

Abstract: Heat generation inside of the battery cell is one of the most important factors affecting the life time of batteries. Due to increasing of daily use of batteries, the thermal analysis methods of the batteries get importance by the researchers. In this study, the heat generation inside of the pouch battery cell is investigated. In order to validate the numerical results, the experiments are performed for $1 \mathrm{C}$ and $2.5 \mathrm{C}$ discharge rates of $3.7 \mathrm{~V}, 2.1 \mathrm{Ah}$ battery cell. The electrical equivalent circuit thermal model is taken into account in order to simulate the heat generation inside of the battery cell. The comparison of the numerical results with the experimental data showed that there is a good consistency with numerical and experimental results. Validation of the model with the experimental data is in the $4 \%$ error band. The model can be used for other discharge rates.
\end{abstract}

*Sorumlu yazar: gamze.gediz@okan.edu.tr 


\section{Introduction}

Due to social life style change in the world, the batteries and their usage area increase. The batteries start to be used in daily life from cell phones to electric vehicles. Many researchers study on battery thermal modelling of lithium ion, lithium phosphate batteries that are favored for small portable devices. Nowadays, one of the most important research topic is the Battery Thermal Management (BTM). The battery affects directly the performance of the device. That is why, the energy saving and the safety of the battery need more attentions. The type of the battery, the battery pack type, and the weight of the battery should be investigated carefully in order to achieve maximum performance. Furthermore, the battery temperature should be analyzed carefully to find out critical values. In hard and extreme conditions, such as very high or low ambient temperatures, hard abuse usage, the BTM should be analyzed very well.

The heating and cooling mechanisms of the batteries are a major focus area of research. The heating/cooling mechanism (thermal control) of the batteries effects the life time of the batteries. The high temperature inside of the battery may cause the battery to explode and low temperature can block the battery so that it does not work properly. For instance, in the study of Chiu et al. [1], the life time of the Li-ion battery with temperature was experimentally studied. Two batteries were connected in series and different ambient temperatures were applied. They compared the results when both the batteries are at $250 \mathrm{C}$, or one is $25 \mathrm{oC}$ and other one is $550 \mathrm{C}$. The results showed that temperature difference generates a higher decrease in the active Li-ion concentration as time evolves. The higher decrease corresponds to a faster capacity fade during cycling. That's why the problem of modeling the thermal control of the battery is a significant research area in order to develop efficient BTM mechanism. The heat generation inside of the battery cell should be investigated and the coolingheating loads should be studied in detail.

Based on the performed review, battery thermal models can be classified into two groups as numerical/analytical models and behavioral models. The lumped capacitance model is one of the preferable numerical/analytical models for simulating the battery thermal distribution. Hallaj et al. [2] used this model in order to simulate temperature profiles inside of a lithium ion battery cell (Sony US18650) from 10 Ah to 100 Ah for different ambient conditions. The other numerical/analytical battery model is 2D transient finite difference analysis thermal model. This model finds and approximates the solution to boundary value problems of partial differential equations. Karimi et al. [3], Inui et al. [4], and Onda et al. [5] used this model for battery cell performance. Another numerical/analytical model is numerical thermal model with analytical validation. Xun et al. [6] and Ling et al. [7] validated their analytical model with numerical models. Behavioral models or electrical equivalent circuit thermal models are also widely used to simulate thermal behavior of the battery. The temperature change and the heat generation inside of the battery cell is modeled as electrical equivalent circuits. Huria et al. [8], Damay et al. [9], and Saw et al. [10] used $1 \mathrm{RC}$ or 2RC equivalent models in order to simulate the temperature distribution inside of the battery cell. The heat generation can be modelled easily by using an electrical equivalent circuit model. The aim of these studies on thermal management of batteries is to estimate the heat generation inside of the battery, thus the temperature change during usage. 
This study aims to model the heat generation inside of the battery cell. By this target, the behavioral battery model was taken into account in order to simulate the heat generation inside of the battery cell. The variation and spatial profile of temperature during discharge (1C, 2.5C) of a battery cell which is Enertech SPB 653496 (2100 mAh, 3.7 V) type battery is modelled and experimentally evaluated. The experimental results were correlated with the 3D model which is modelled in Comsol 4.5. The simplified layer model is used in this study and in order to decrease the computational time, the battery is not modelled layer by layer for each material which is used inside of the battery cell. The total thermal conductivity is calculated for the overall battery. The comparison results showed that the electric equivalent circuit model for the battery cell is valid in order to simulate the heat generation inside of the battery cell by a simplified layer model.

\section{Material and Method}

\subsection{Experimental setup}

A $2100 \mathrm{mAh}$ pouch Li-ion cell with dimensions of $34 \mathrm{~mm}$ width, $96 \mathrm{~mm}$ long, and $6.5 \mathrm{~mm}$ thick is modeled for all simulations. The battery is shown in Figure 1. The Neware BTS type battery test equipment was used for the experiments as illustrated in Figure 2(a). Neware has AC input power as $220 \mathrm{~V}$ $\pm 10 \%$ with $50 \mathrm{~Hz} / 60 \mathrm{~Hz}$, and the output range as $0-110 \mathrm{~V}$. Its measuring accuracy is $\pm 0.1 \%$ of FS. The tested battery connections and the thermocouple which is attached on the surface of the battery cell body $(10 \mathrm{~mm}$ below from the top) are given in Figure 2(b). The tests were performed for $1 \mathrm{C}$ and 2.5C discharge rates. Figure 3 illustrates the discharge curves of the battery cell at ambient temperature during the experiments.

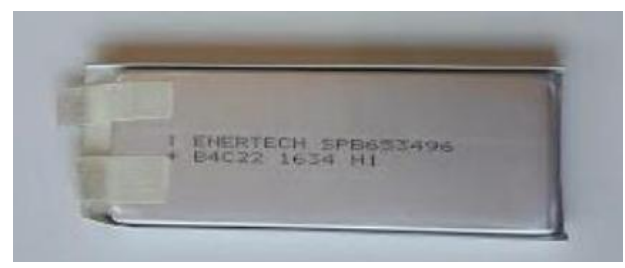

Figure 1. ENER1 - SPB653496H - 3.7V / 2.1Ah Li-ion battery cell

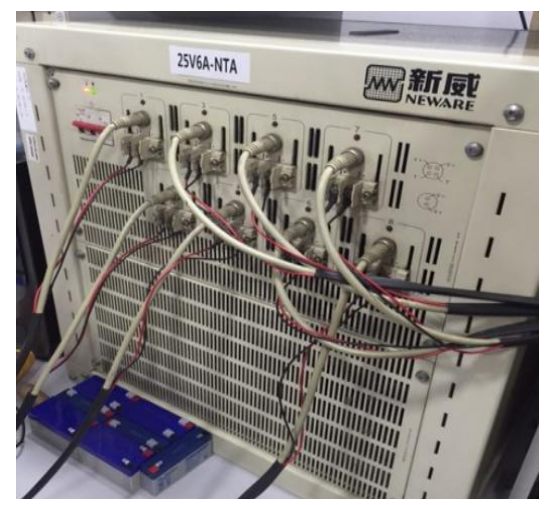

(a)

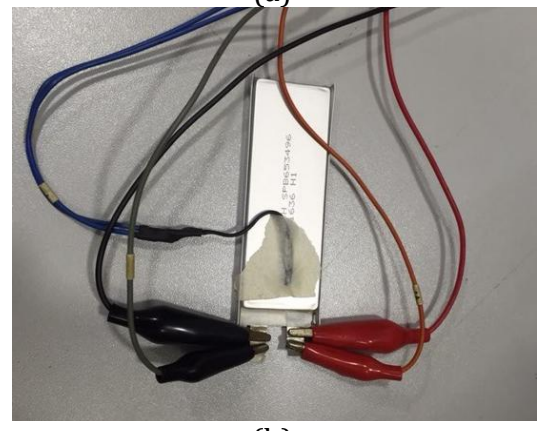

(b)

Figure 2. a) Neware test apparatus, b) Connection detail of the battery cell

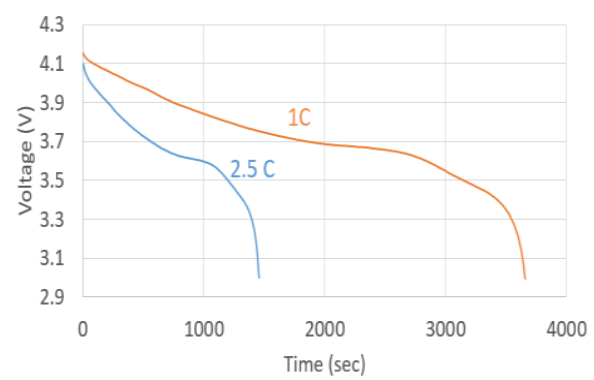

Figure 3. Discharge curves

\subsection{Numerical model}

According to the geometry and structure of the battery, a three-dimensional model 
is built by using Comsol 4.5, and shown in Figure 4. The selected point in Figure 4(b) represents the thermocouple location which is given in Figure 2(b).

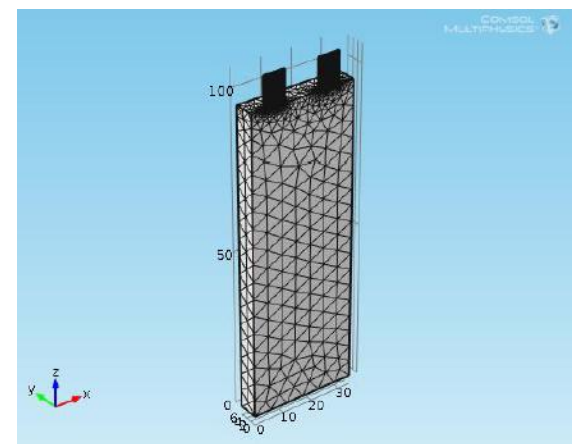

(a)

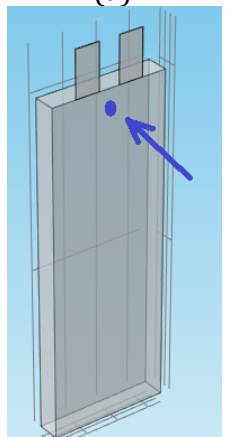

(b)

Figure 4. The model of the battery cell, a) the mesh, b) the simulation point of the thermocouple

In this study, electrical equivalent circuit thermal model is chosen in order to calculate the heat generation inside of the battery cell. The first-order RC model is shown in Figure 5.

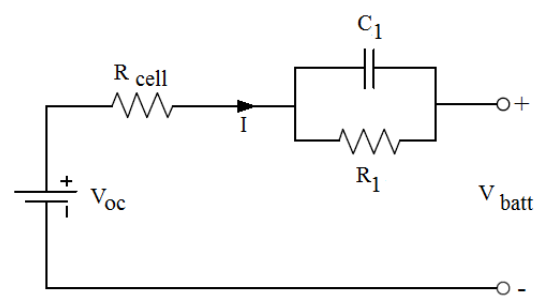

Figure 5. Equivalent circuit diagram for the single RC battery model

The energy conservation of the battery can be found as follows;

$$
\left(\rho C_{p}\right)_{\text {cell }} \frac{\partial T}{\partial t}=\lambda \nabla^{2} T+\dot{q}
$$

where, $C_{p}, T, t, \lambda, \dot{q}, \rho$ represent the mean density of the battery, the mean specific heat of the battery, temperature, time, thermal conductivity of the cell, heat generation inside the battery, and density, respectively. The heat generation can be due to irreversible and reversible (chemical reaction) reactions. The heat generation due to chemical reaction can be neglected and the irreversible heat generation can be found by;

$$
\dot{q}=I\left(V_{o c}-V_{b a t t}\right)=I^{2} R_{c e l l}
$$

In this study, the cell resistance is measured as $4.11 \mathrm{~m} \Omega$ when the battery is full. But as known from the literature [10], the internal resistance (Rcell) increases rapidly approximately twice so in this study internal resistance assumed as constant $7 \mathrm{~m} \Omega$. As known, the internal resistance changes with the state of charge (SOC) of the battery. But during the experiments, the change of internal resistance of the battery cell vs SOC cannot be measured. So in the calculations, it is considered constant.

Also, thermophysical properties of the battery cell should be correlated. The internal structure of Li-ion batteries should be known in order to calculate these properties (density, thermal conductivity, specific heat). The Li-ion batteries are formed by repeated pressing of material blocks. The structure of the blocks causes the battery thickness. These material layers are formed from copper foil, negative electrode, separator, aluminum foil, and positive electrode. The battery built up by addition of anode-cathode tabs and aluminum shield. The thermophysical properties of these materials are given in Table 1 [11]. 
As seen from Table 1, the thermal conductivity coefficient of the battery is anisotropic. The lithium-ion batteries are made up of these layers of different materials which are divided by electrolyte.

The thermal conductivity of the battery cell should be calculated in parallel and in series [12]. The thermal conductivity coefficient in parallel and in series can be determined by;

$$
\begin{aligned}
& \lambda_{x}=\lambda_{z}=\frac{\lambda_{i} L_{i}}{L_{y}} \\
& \lambda_{y}=\frac{L_{y}}{\frac{L_{i}}{\lambda_{i}}}
\end{aligned}
$$

$\lambda_{x}, \lambda_{y}, \lambda_{z}$ are the thermal conductivity coefficients of the battery materials at the directions of $\mathrm{x}, \mathrm{y}$ and $\mathrm{z}$, respectively. The mean specific heat capacity of battery can be calculated by;

$$
\sum \rho_{\text {cell }} C_{p_{\text {cell }}}=\frac{\sum \rho_{i} C_{p_{i}} V_{i}}{\sum V_{i}}
$$

$\rho_{c e l l}$ and $C_{p_{c e l l}}$ are the mean density of the battery and the mean heat capacity of the battery. $\rho_{i}$ and $C_{p_{i}}$ are the density and the specific heat capacity of each material. $V_{i}$ is the volume of each material (Table 1)

The initial temperature of the simulation were taken same with the ambient temperature when the experiments are held at $21.2^{\circ} \mathrm{C}$. The heat transfer coefficient is considered as natural convection at the surface of the battery and taken as $5 \mathrm{~W} / \mathrm{m}^{2} \mathrm{~K}$. In order to understand if the model works properly or not, the convection coefficient such as $10 \mathrm{~W} / \mathrm{m}^{2} \mathrm{~K}$ is also compared with the experimental results.

Table 1. Thermophysical properties parameters of the lithium-ion battery materials [11]

\begin{tabular}{ccccc}
\hline & $\begin{array}{c}\text { Material } \\
\text { Thickness, L } \\
(\mathrm{mm})\end{array}$ & $\begin{array}{c}\text { Density, } \rho \\
\left(\mathrm{kg} / \mathrm{m}^{3}\right)\end{array}$ & $\begin{array}{c}\text { Specific } \\
\text { Heat,Cp } \\
(\mathrm{J} / \mathrm{kgK})\end{array}$ & $\begin{array}{c}\text { Thermal } \\
\text { Conductivity, } \lambda \\
(\mathrm{W} / \mathrm{mK})\end{array}$ \\
\hline $\begin{array}{c}\text { Pouch } \\
\text { Separator }\end{array}$ & 0.5 & 2702 & 903 & 238 \\
$\begin{array}{c}\text { Electrode material of } \\
\text { positive electrode }\end{array}$ & 0.035 & 492 & 1978.2 & 0.334 \\
$\begin{array}{c}\text { Electrode material of } \\
\text { negative electrode } \\
\text { Aluminum foil }\end{array}$ & 0.14 & 1500 & 1260.2 & 1.48 \\
$\begin{array}{c}\text { Copper foil } \\
\text { Aluminum laminate } \\
\text { film }\end{array}$ & 0.116 & 2660 & 1437 & 1.04 \\
$\begin{array}{c}\text { Tab of positive } \\
\text { electrode }\end{array}$ & 0.014 & 2702 & 903 & 238 \\
$\begin{array}{c}\text { Tab of negative } \\
\text { electrode }\end{array}$ & 0.14 & 1636 & 1376.9 & 398 \\
$\begin{array}{c}\text { Electrolyte } \\
\text { leate }\end{array}$ & 0.116 & 8933 & 903 & 238 \\
\hline
\end{tabular}

\section{Validation of Results}

The numerical results are validated with the experimental results for two different discharge rates as $1 \mathrm{C}$ and $2.5 \mathrm{C}$.
As illustrated from Figure 4(b), the thermocouple location is taken into account. The numerical solutions for this point were compared with the 
experiments and given in Figure 6. The dashed lines represent the numerical solution results where the others are from the experiments. The experiments took $3660 \mathrm{sec}$ and $1455 \mathrm{sec}$ for $1 \mathrm{C}$ and 2.5C, respectively. That's why, the duration of the numerical solutions were taken same with the experiments.
Shaded areas are the error bands and $\% 4$ is found from the uncertainty analysis of the thermocouple and the components which are used in experiments. As seen, the numerical results are in good correlation with the experimental

data.

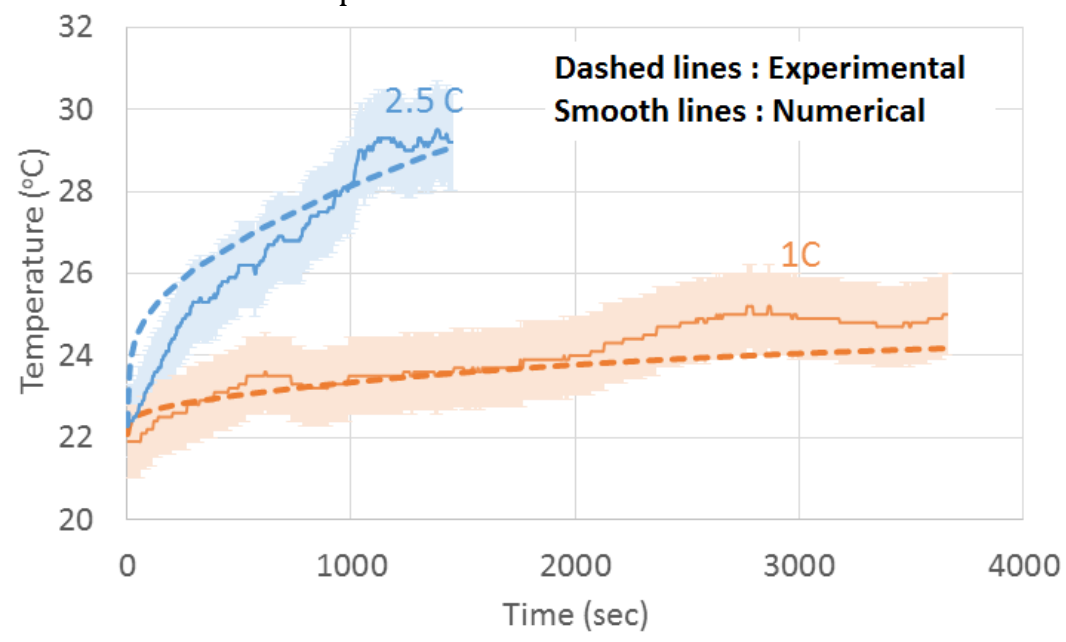

Figure 6. The validation of numerical results with experimental results of the specified point.

\section{Thermal Investigation of the Results}

As mentioned in Section 2.1, the experiments were performed by using the Neware BTS type battery test equipment. This device has limited specifications. For instance, only one temperature measurement can be performed during the tests. So, the surface temperature was able to measure at one point from the surface. This device has capability up to $6 \mathrm{~A}$. So due to the safety, the measurements was not allowed up to $2.5 \mathrm{C}$. The calibration of the system includes all charge voltage, charge current, discharge voltage, and discharge current. The calibration of the thermocouple was performed by using Fluke 714 thermocouple calibrator.

After the validation, the average temperature for the battery cell are investigated. The volume average temperature gradient at the end of the discharge duration is illustrated in Figure 7 for both $1 \mathrm{C}$ and 2.5C discharge rates. As seen from Figure $7(\mathrm{a})$, the maximum average temperature at the end of $3660 \mathrm{sec}$ is approximately $25.6^{\circ} \mathrm{C}$ which is at the anode and cathode locations for 1C discharge rate. The lowest temperature is seen at the bottom location of the battery cell as expected. The same temperature gradient is also seen for $2.5 \mathrm{C}$ discharge rate as given in Figure 7 (b). For $2.5 \mathrm{C}$ discharge rate, the maximum temperature reaches to 35.6 oC where the lowest temperature is at $250 \mathrm{C}$ at the end of $1455 \mathrm{sec}$. As the duration of the discharge decreases, the discharge rate increases and also the heat generation increases in the battery cell. As seen from the temperature scale given on the right side of the figure, temperature distributions on the external surfaces of the battery cell increases around $24{ }^{\circ} \mathrm{C}$ 
and and $26{ }^{\circ} \mathrm{C}$ for 1 and $2.5 \mathrm{C}$ discharge rates, respectively. As given in the validation section, the temperature change due to discharge can be extended for other discharge rates.

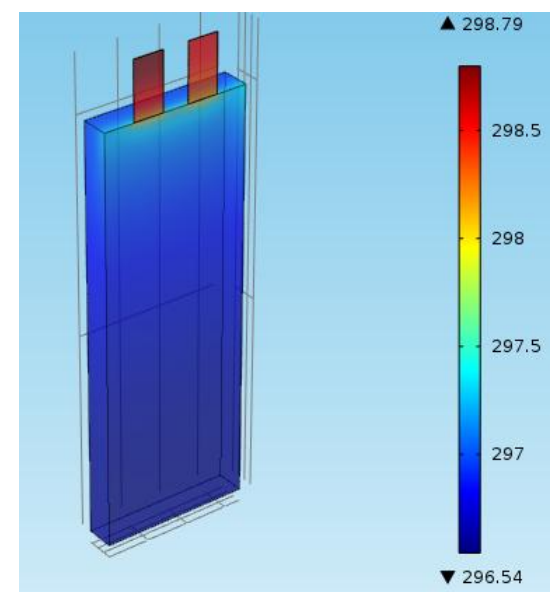

(a)

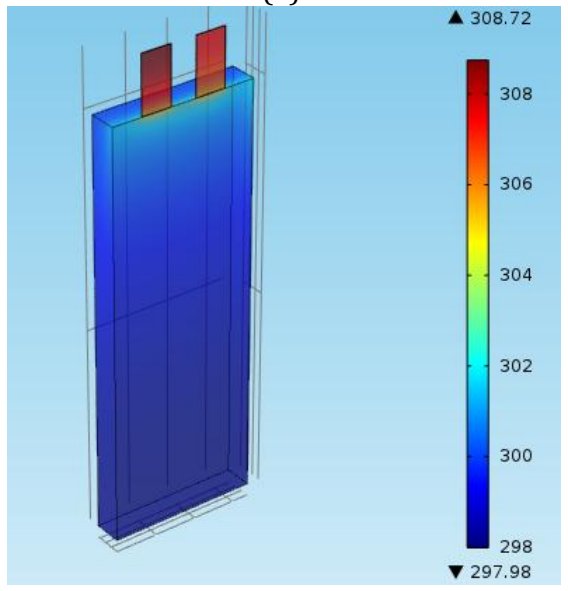

(b)

Figure 7. The simulation results, a) $1 \mathrm{C}$ discharge results at $3660 \mathrm{sec}$, b) $2.5 \mathrm{C}$ discharge results at $1455 \mathrm{sec}$

The temperature change in battery cell during the discharge for both $1 \mathrm{C}$ and 2.5C discharge rates and different convection coefficients is also given in Figure 8. The volume average temperature was simulated both for $1 \mathrm{C}$ and $2.5 \mathrm{C}$ discharge rates and also the effects of convection coefficient for these discharge rates are investigated. As seen, the volume average temperature increases with the discharge rate. But with the increase of the convection coefficient, the temperature decreases as expected. So the results concluded that, the model works properly.

\section{Conclusion}

The heat generation inside of the $3.7 \mathrm{~V}$, 2.1 Ah pouch battery cell is both experimentally and numerically investigated in this study. The experiments are performed both for $1 \mathrm{C}$ and $2.5 \mathrm{C}$ discharge rates, and during the discharge, the temperature change at the surface of the battery cell is measured. The collected experimental results are compared with the numerical solutions which are developed by using the electrical equivalent circuit thermal model and a simplified layer method. The simplified layer model is considered in order to decrease the mesh size and the computational time. Heat generation is modelled inside of the battery cell with Comsol 4.5. The validation of the model is performed with the experimental results both for $1 \mathrm{C}$ and $2.5 \mathrm{C}$ discharge rates. The results showed that, the electrical equivalent circuit thermal model can be used in order to simulate heat generation inside of the battery cell. In the future, both the performance change of the battery with the internal resistance change (Rcell) vs state of charge (SOC) and the other discharge rates will be analyzed and the results will be concluded. 
G. Gediz Illiş / Thermal Investigation of Pouch Battery Cell with Different Discharge Rates

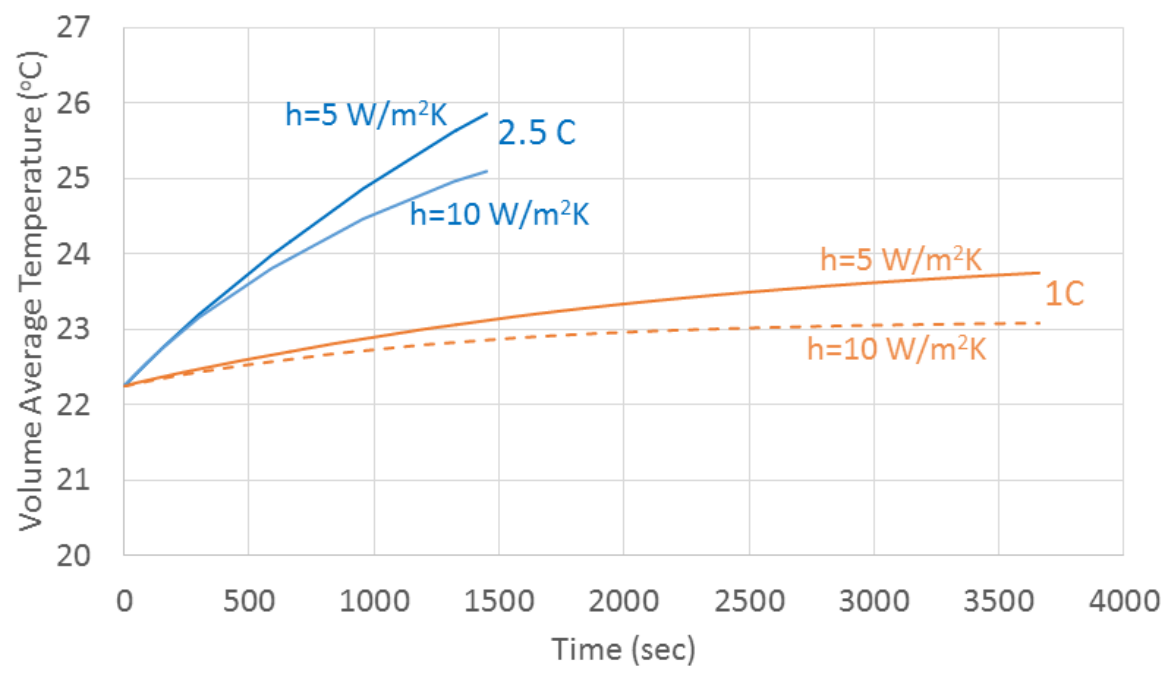

Figure 8. The temperature change in battery cell for both $1 \mathrm{C}$ and $2.5 \mathrm{C}$ discharge rates for different convective coefficients

\section{Acknowledgment}

The author thanks to Birikim Pilleri Batarya Sanayi ve Ticaret Ltd. Ști. for assistance in experimental work.

\section{References}

[1] Chiu, K.C., Lin, C.H., Yeh, S.F., Lin, Y.H., Huang, C.S., Chen, K.C. 2014. Cycle life analysis of series connected lithium-ion batteries with temperature difference, Journal of Power Sources, vol. 263, pp. 75-84.

[2] Hallaj, S.A., Maleki, H., Hong, J.S., Selman, J.R. 1999. Thermal modeling and design considerationsof lithium-ion batteries, J. Power Sources, vol. 83, pp. 1-8.

[3] Karimi, G., Li, X. 2013. Thermal management of lithium-ion batteries for electric vehicles, Int. J. Energy Res., vol. 37, pp. 12-24.

[4] Inui, Y., Kobayashi, Y., Watanabe, Y., Watase, Y., Kitamura, Y. 2007. Simulation of temperature distribution in cylindrical and prismatic lithium ion secondary batteries, Energy Convers. Management, vol. 48, pp. 21032109.
[5] Onda, K., Ohshima, T., Nakayama, M., Fukuda, K., Araki, T. 2006. Thermal behavior of small lithiumion battery during rapid charge and discharge cycles, Journal of Power Sources, vol. 158, pp. 535542.

[6] Xun, J., Liu, R., Jiao, K. 2013. Numerical and analytical modeling of lithium ion battery thermalbehaviors with different cooling designs, J. Power Sources, vol. 223, pp. 47-61.

[7] Ling, Z., Chen, J., Fang, X., Zhang, Z.X., Taon, X., Gao, X., Wang, S. 2014. Experimental andnumerical investigation of the application of phase change materials in a simulative powerbatteries thermal management system, Appl. Energy, vol. 121, pp. 104-113.

[8] Huria, T., Massimo, C., Jackey, R., Gazzarri, J. 2012. High fidelity electrical model with thermaldependence for characterization and simulation of high power lithium battery cells, In Proceedingsof the 2012 IEEE International Electric Vehicle Conference (IEVC), Greenville, SC, USA, 1-8. 
[9] Damay, N., Forgez, C., Bichat, M.P., Friedric,h G. 2015. Thermal modeling of large prismaticLiFePO4/graphite battery. Coupled thermal and heat generation models for characterization and simulation, J. Power Sources, vol. 283, pp. 3745.

[10] Saw, L.H., Ye, Y., Tay, A.A.O. 2013. Electrochemical-thermal analysis of 18650 lithium ironphosphate cell, Energy Convers. Management, vol. 75, pp. 162-167.

[11] Du, S., Jia, M., Cheng, Y., Tang, Y., Zhang, H., Ai, L., Zhang, K., Lai, Y. 2015. Study on the thermal behaviors of power lithium iron phosphate (LFP) aluminumlaminated battery with different tab configurations, International Journal of Thermal Sciences, vol. 89 pp. 327-336.

[12] Chen, S.C., Wan, C.C., Wang, Y.Y. 2005. Thermal analysis of lithiumion batteries, J. Power Sources, vol. 140 (1), pp. 111-124. 